\title{
Professional Employee Retention: Examining The Relationships Between Organizational Citizenship Behavior And Turnover Cognitions
}

Pascal Paillé, Laval University, Canada

Nicolas Raineri, Louvain School of Management Research Institute, Belgium

Patrick J Valeau, University of Reunion, France

\begin{abstract}
The purpose of this study is to examine the relationships between organizational citizenship behaviour, intention to search a job, intention to leave the organization, and the profession. Using a sample of social workers $(N=327)$, findings show that while intention to leave the employer is explained by helping, civic virtue and sportsmanship, intention to leave the profession is explained only by civic virtue and sportsmanship. The implications of the findings are discussed.
\end{abstract}

Keywords: Employee Retention; Organizational Citizenship Behavior; Professional Employees

\section{INTRODUCTION}

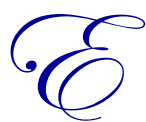

mployee withdrawal occurs when an employee exhibits an inclination to disengage from the workplace if the latter is deemed to affect physical or mental health (Gupta and Jenkins, 1983). Lateness, absenteeism and turnover are the major forms of withdrawal behaviour (Hanish and Hulin, 1990;

Rossé, 1988). Following Boswell and Olson-Buchanan (2004, p. 130) "withdrawal may also come in the form of adaptive behaviours whereby an employee lessens participation in the work situation yet maintains membership in the organization." Deviance literature (for example, Boswell and Olson-Buchanan, 2004; Robinson and Bennett, 1995) adds another form of behaviour tantamount to withdrawal in the workplace that includes being absent when not really sick, working slowly, taking excessively long breaks or long lunch periods, etc. (for a more complete list see Robinson and Benett, 1995). Both types of literature on job satisfaction and employee commitment report extensive data showing that when employees are dissatisfied with their jobs or become less committed to their organizations, they are prone to engage in a withdrawal process (Hom and Griffeth, 1995). Increasingly, the link between organizational citizenship behaviour (OCB) and employee withdrawal has become a focal point of research. Many empirical studies have found a significant negative correlation indicating that OCB promotes employee retention (Chen, 2005; Chen, Hui and Sego, 1998; Coyne and Ong, 2007; MacKenzie, Podsakoff and Ahearne, 1998; Podsakoff, Whiting, Podsakoff, and Blume, 2009). These previous findings are consistent with Harrison, Newman and Roth (2006), who provide empirical evidence supporting a view of OCB as the initial stage of employee withdrawal. Because OCB is recognized as a form of discretionary behaviour, not formally required in the workplace (Organ, Podsakoff and MacKenzie, 2006), it is less risky for employees to reduce OCB than to exhibit deviant behaviour or to express discontent by increasing their rate of absenteeism. In practical terms, this means, for example, that a low level of OCB is a significant indicator that may reflect an intended process of withdrawal from the organization.

Recent literature has largely overlooked the link between OCB and changing professions. In most studies, employee retention is restricted to the notion of an employee leaving an organization to join another organization. However, employee retention may legitimately be expanded to include changing professions. Changing employers and changing professions are significantly different processes. A change of employer occurs when an employee 
disengages from a work environment perceived as being physically and psychologically harmful. In such case, employers are forced to compete within the same sector of activity. With a change of profession, the work environment, rather than the profession, is deemed to be detrimental to physical and mental health. As a result, different sectors of activity in the labour market are forced to compete. Although this issue has been examined in a small number of studies (Parry, 2008; Wermeling, 2009), the distinction is rarely made in the current literature on employee retention. Parry (2008) explains this by emphasizing the methodological choices made by scholars in the field that make it impossible to establish whether employees leave their employer or their profession. Recent methodological approaches have produced ambiguous data that have served only to increase the confusion in research on employee retention.

The purpose of this article is to improve our understanding of the relationship between OCB and employee retention by examining the links between facets of OCB and withdrawal cognitions such as job search, intention to leave the employer and the profession. The article begins with a literature review before outlining the findings of a field study on social workers. The field study aims to determine how OCB is linked to changing professions and intention to leave. Finally, the results are discussed in light of the literature review.

\section{THEORETICAL BACKGROUND}

\section{OCB and Leaving the Employer}

Relationships between OCB and turnover intentions are well documented. Based on a meta-analytical examination, Podsakoff, Whiting, Podsakoff and Blume (2009) reported that overall OCB toward the organization and turnover intentions are negatively related ( $\mathrm{r}$ corrected $=-.22, \mathrm{k}=90, \mathrm{~N}=26510)$, suggesting that the more employees demonstrate OCB, the less they want to leave their organization. However, most previous research examines OCB as a whole. Following Organ's framework, the willingness to cooperate refers to OCB towards the organization in the form of sportsmanship and civic virtue, and OCB directed toward individuals in the form of helping others.

Helping occurs when an employee provides technical or moral support to a co-worker to help the person (for instance) solve a complex problem or overcome temporary setbacks at work. Following Organ et al. (2006, p. 201) "helping behaviours may enhance morale, group cohesiveness, and a sense of belonging to a team, all of which may enhance performance and help the organization to attract and retain better employees." Additional results provided by Podsakoff et al. (2009) indicate that OCB towards individuals affects turnover intentions ( $\mathrm{r}$ corrected $=$ $-.11, \mathrm{k}=40, \mathrm{~N}=10337)$. Given these previous results, we hypothesize the following:

Hypothesis 1: OCB towards individuals and intention to leave the employer are negatively related.

Podsakoff et al. (2009) indicate that OCB towards the organization affects turnover intentions ( $\mathrm{r}$ corrected $=-.20, \mathrm{k}=37, \mathrm{~N}=9671$ ). Despite the large body of literature, it is not clear if sportsmanship better explains an intention to leave the employer than civic virtue. Therefore, more work is needed. We believe that the decomposition of OCB into several facets is an interesting avenue, more specifically so for OCB towards the organization.

Civic virtue typically reflects a macro-level interest in the organization as a whole. Civic virtue refers to a sustained interest in the organization, expressed in a variety of ways, including assiduous and voluntary involvement in representation activities (for example conferences, trade fairs and workshops, etc.) and in the defence of the interests, property or image of the organization. As such, civic virtue occurs by participating actively and voluntarily and by requiring of individuals the desire to be involved, for example, in decision making by formulating new ideas, suggesting improvements during seminars or meetings or protecting the organization (Organ et al., 2006). In so doing, the employee demonstrates a deep interest in the political life of the organization. Until now, with the exception of Coyne and Ong (2007), little work has been done to examine the effect of civic virtue on turnover intentions. While Coyne and Ong (2007) did not find significant relationships between civic virtue and turnover intentions, they did recognize that features of the sample (size and participants) may minimize the statistical power of their data. However, literature on whistle-blowing may help to understand the processes underlying OCB and 
intention to leave the employer. Because whistle-blowing is viewed as a distinct form of extra-role behaviour (Van Dyne, Cummings, and McLean Parks, 1995), previous literature on whistle-blowing provides useful findings. Although some authors like Furnham and Taylor (2004) argue that outcomes of whistle-blowing may not be universally viewed as "good", Dozier and Miceli $(1985$, p. 826) suggest that whistle-blowing is a form of pro-social behaviour, because it will generally prove to be beneficial to organizations other than the whistle-blower's. Whistleblowing occurs when an employee speaks up to protect the organization from a perceived threat (Moon, Van Dyne and Wrobel, 2005). An employee exhibiting civic virtue demonstrates a willingness to make suggestions to improve quality (Koys, 2001), remain informed about current (and potential) issues of organizational importance (Graham, 1995) or contribute responsibly to corporate governance (Motowidlo, 2000). Because these kinds of mind-set reflect an employee's sense of commitment toward the organization, it is somewhat incompatible with the desire to leave the employer. Therefore, we hypothesize the following:

Hypothesis 2: Civic virtue and intention to leave the employer are negatively related.

Sportsmanship reflects a posture of tolerating the inconveniences of work. According to Organ (1988), sportsmanship occurs when an employee tolerates inconveniences and abuse linked to excessive work demands without complaining. As such, sportsmanship occurs when an employee is willing to roll with the punches, not complain about trivial matters and set about being an example for others (Organ et al, 2006). Previous findings have demonstrated the direct, negative impact of role ambiguity (Chu, Lee, and Hsu, 2006) and the direct, positive impact of workload (Miles, Borman, Spector and Fox, 2002) on organizational citizenship behaviour. Miles and his colleagues suggest that "a high workload can be stressful and perceived in a negative manner, but may also create (at least from the worker's perception) the opportunity to persevere and continue to work in spite of difficult conditions." Because sportsmanship refers to the willingness to tolerate a high workload, the literature on job demands (work pressure, workload, emotional demands, etc.) provides some interesting results that may help to understand the association between sportsmanship as a form of OCB directed towards the organization, and intention to leave the employer. Job demands (part of Karasek's Job Demand-Control model) refer to the workload, and have been operationalized mainly in terms of time pressure and role conflict (Van der Doef and Maes, 1999). Although results indicate that job demands affect intention to leave the organization (Schaufeli and Bakker, 2004) through burnout, data compiled by Bakker and Demerouti (2007) suggest that employees can work under pressure (high job demands) when they perceive that their work environment provides resources such as support, feedback, supervisory coaching, autonomy, etc. Likewise, these developments are compatible with recent findings. Coyne and Ong (2007) were the first to show a negative link between sportsmanship and turnover intentions. Moreover, they believe that an individual who behaves in this manner (demonstrates good sportsmanship) is more likely to be committed to the organization and less likely to have a negative image of the work environment, and is less likely to want to withdraw from the work environment. Therefore, we hypothesize the following:

Hypothesis 3: Sportsmanship and intention to leave the employer are negatively related.

\section{OCB and Leaving the Profession}

Very little has been said About the links between OCB and leaving the profession. Some studies (Cohen, 2003) have shown that a career change (profession) often involves a change of job and organization. While the effects of turnover rates are clearly an issue for employers (Holtom, Mitchell, Lee and Inderrieden, 2004), the consequences of a high level of withdrawal from a profession also have significant societal implications (Krausz et al., 1995). Recent literature provides no conclusive data demonstrating a correlation between OCB and intention to leave a profession.

Research focusing on cognate themes may help to determine the links between OCB and profession. The literature on internal career paths or career plateaus provides useful results. For example, Chompookum and Derr (2004) examine the links between internal career paths and OCB. Their findings indicate that individuals developing a secure career path exhibit a higher level of OCB than individuals engaged in a freer career path. It was found that while the former tend to favour job safety over loyalty and effort, the latter tend to maintain control of their career paths and use their career as a means of achieving personal goals. Research on career plateaus has also yielded a number of interesting findings. A career plateau is defined as the sense of failure or frustration experienced by an 
individual as a result of a temporary or permanent interruption in their career progression (Lemire, Saba and Gagnon, 1999). Near (1984) reports data indicating that higher levels of absenteeism are found among managers who feel they have reached a career plateau than among managers who feel their career has not reached a plateau. Although, Chay, Arye and Chew (1995) measure extra-role behaviour rather than OCB, they report findings indicating that the perception of a career plateau affects the willingness to engage in extra-role behaviour. Extra-role behaviour encompasses several kinds of behaviour such as stewardship, political behaviour and OCB (Eastman and Pawar, 2005). Because these kinds of behaviour are described as discretionary and not directly recognized by the employer (Van Dyne and Lepine, 1998), and as such are close to OCB, findings obtained by Chay et al. (1995) provide useful indications. A more recent study shows that career plateau increases intention to leave (Foster, Shastri and Witane, 2004). Consistent with Harrison et al. (2006), who found that OCB is the first stage of the withdrawal process, the results outlined above indicate that the sense of having reached a career plateau affects every stage of the withdrawal process - from a declining willingness to engage in OCB to intention to leave.

The relationship between professional commitment and OCB toward the individual is well established, suggesting that the more a person is committed to his or her profession, the more he or she willing the person will be to demonstrate helping behaviour towards a colleague or another individual (e.g., Meyer, Allen, and Smith, 1993; Rhee, Park and Hwang, 2011). Among others findings, Meyer et al. (1993) found that commitment to the occupation correlates positively with helping behaviour and negatively with intention to leave the occupation. Using a sample of nurses, Lu, Lin, Wu, Hsieh and Chang (2002) reported that professional commitment is more effective in predicting intention to leave the profession than intention to leave the organization. If commitment to the profession is positively related to helping others and negatively related to intention to leave the profession because (give and receive) helping reflects a positive work experience (Organ et al., 2006), it seems reasonable to expect a negative relationship between OCB toward others and intention to leave the profession. Therefore, we hypothesize the following:

Hypothesis 4: OCB toward the individual and intention to leave the profession are negatively related.

To date, the way that civic virtue is empirically related to the desire to leave a profession has yet to be explored. Although the issue tends to be overlooked in the literature, the link between OCB and profession has a solid theoretical foundation. Lavelle (2010) recently set out to explore the links between OCB and opportunities for career development from a theoretical perspective. Lavelle's arguments were based on the example of civic virtue. As noted above, an employee who takes part voluntarily in events or workshops exhibits a high level of civic virtue. By representing the employer at a trade fair, an employee is likely to meet members of other organizations. While contacts may be limited to business relations for the benefit of the employer of each employee, an employee may find that a professional contact develops into a potential new employer in the course of representing the interests of the current employer. Therefore, a new job opportunity may arise. Despite this interesting argument, the outcome depends on the level of civic virtue displaying by the employee. While a high level civic virtue reflects a personal interest for organizational issues, a low level does not. Previous findings (Yoon and Suh, 2003) reported a positive relationship indicating that the more an employee is committed to the organization, the more the employee demonstrates personal interest for governance issues. In addition, based on a literature review of career commitment, Kidd and Green (2006) collected findings indicating "that there is no inherent conflict between commitment to the profession and organization if the professional's work expectations and goals are met by the employing organization" (p. 234). In accordance with Kidd and Green (2006), when an individual shares organizational goals and displays some degree of agreement with work environment characteristics, he is more motivated to continue his professional relationship with the employer. Therefore, we hypothesize the following:

Hypothesis 5: Civic virtue and intention to leave the profession are negatively related.

Sportsmanship is a type of citizenship behaviour indicative of a willingness to tolerate excessive demands and pressure without complaining. Based on several empirical studies, sportsmanship seems compatible with the desire to exit from a stressful profession to join a profession perceived as less stressful. Bolino and Turnley (2005) found that excessive level of OCB may induce dysfunctional outcomes such as overload and stress. A number of professions (nurses, social workers, teachers, research scientists, correctional staff, etc.) are well known for causing significant stress and exhaustion. While Blau and Luz (1998) have reported that employees satisfied with their job 
display a propensity for remaining in their profession, previous empirical research has found that an intention to leave the profession is connected to work-related factors known to affect wellbeing at work. For example, in stressful professions, higher quantitative work demands (Flinkmana, Laineb, Leino-Kilpia, Hasselhorn, and Salanterä, 2008) and work exhaustion (Blau, 2009) were found to be important determinants of intention to leave the profession. Moreover, because sportsmanship is conceptualized as discretionary behaviour (Organ, 1988), additional findings in a teaching context provided by Rosenholtz (1989) reported interesting data showing that lack of discretion at work affects commitment to the profession (viewed in her study as part of work commitment), thereby enhancing employee defection. Thus, if, under certain circumstances described by Bolino and Turnley (2005), OCB and stress are positively related and, in turn, stress increases intention to leave the profession, based on these previous findings we may infer that sportsmanship (being a good sport) is compatible with the desire to leave a profession. Therefore, we hypothesize the following:

Hypothesis 6: Sportsmanship and intention to leave the profession are positively related.

\section{Beyond the Direct Effect: a Possible Mediating Role for Job Search}

According to Kanfer, Wanberg, and Kantrowitz (2001), job search refers to a "volitional pattern of action that begins with the identification and commitment to pursuing an employment goal. The employment goal, in turn, activates search behavior designed to bring about the goal." Focusing on job-search behaviour may improve our understanding of the links between OCB, intention to leave the employer and intention to leave the profession. Job search provides useful information and data about job markets that help the employee to make the decision to leave an employer (Steel, 2004). Active job search occurs when an employee believes that he will easily be able to find a new job. A successful job search increases the likelihood of intention to leave the current employer or the current profession. A number of empirical studies have suggested that OCB plays a key role in turnover cognitions. A negative correlation between perceived job alternatives and OCB was shown (Thau, Bennett, Stahlberg and Werner, 2004), indicating that employees continue to engage in OCB when they perceive job mobility as being poor (low job alternatives). While the effect of perceived job alternatives on OCB is known, the literature has yet to provide any conclusive data on the links between OCB and job-search activity. Robust data drawn from previous studies (Mowday, Koberg and MacArtur, 1984; Sager, Griffeth and Hom, 1998) indicate that job search serves to highlight the links between perceived job alternatives and intention to leave the employer. In other words, in a process known as 'turnover cognitions', perceived job alternatives and turnover intentions are related through job search. If perceived job alternatives (not examined in the present study) are related to job search, and if perceived job alternatives have a direct effect on OCB, then we may infer a relationship between OCB, job search and intention to leave the employer and the profession. Therefore, we hypothesize the following:

Hypothesis 7: Helping (a), civic virtue (b) and sportsmanship (c) affect intention to leave the employer through job search.

Hypothesis 8: Helping (a), civic virtue (b) and sportsmanship (c) affect intention to leave the profession through job search.

\section{METHOD}

\section{Participants}

The decision to collect data using a sample of social workers was based on the observation that the retention of social workers is a matter of great concern for employers, as is consideration of the high number of social workers leaving the profession (Wermeling, 2009). The data collection was carried out with the collaboration of the Quebecers social workers association. A total of 1132 individuals were contacted and invited to participate. 327 social work employees responded to the survey $(28.71 \%)$. After having read the invitation to participate in the survey (which explained the overall objectives of the research) and the consent form outlining the ethical guidelines, two respondents chose to withdraw, opting out of the online survey. Therefore, the sample included 325 participants. $89 \%$ of participants were women. $52 \%$ of participants were aged under $40.36 .8 \%$ of respondents had over 15 years 
of professional experience. $65.2 \%$ of respondents worked in an organization with more than 500 employees. $94 \%$ of participants claimed they had good career prospects in their organization.

\section{Measurements}

$O C B$

The scales developed by Podsakoff and MacKenzie (1994) were used to operationalize organizational citizenship behaviour. A six-item scale was used to measure helping. A four-item scale was used to measure sportsmanship. A three-item scale was used to measure civic virtue. Since this research was conducted in a Frenchlanguage context, the scales validated in French by Paillé (2009) were used. A confirmatory factor analysis shows that the four-factor model was a better fit, $\chi^{2}(61, \mathrm{~N}=228)=120,63, \mathrm{p}<.001, \mathrm{CFI}=.92$, NNFI $=.92$, et RMSEA $=$ .06 , than the three-factor model $\chi^{2}$ diff $(1)=76,57, p<.001$, and the one-factor model $\chi^{2}$ diff $(4)=303,87, p<.001$. The results suggest that French Canadian employees tend to identify helping (Cronbach's alpha, .75), civic virtue (Cronbach's alpha, .74) and sportsmanship (Cronbach's alpha, .72) as salient forms of OCB when using the scales developed by Podsakoff and MacKenzie (1994).

\section{Withdrawal cognitions}

Intention to leave the organization was measured using the scale of Lichtenstein, Alexander, McCarthy, and Wells (2004). Internal consistency (calculated using Cronbach's alpha) was .90. Intention to leave the profession was measured using an adapted version (for example, I often think about leaving the social work profession) of the scale used by Lichtenstein et al. (2004). In the revised version, the phrase 'current employer' was replaced by 'profession'. Internal consistency (calculated using Cronbach's alpha) was .88 . Job search was measured using the three-item scale used by Peters, Jackofsky and Salter (1981). Internal consistency was .89.

All the items were measured using a seven-point Likert scale with responses ranging from 1 (completely disagree) to 7 (completely agree).

\section{RESULTS}

The data analysis involved a two-stage process, in line with the recommendations of Anderson and Gerbing (1988). First, the measurement model was examined to assess the independence of the constructs. Secondly, structural equation modeling (SEM) was used to examine the links between the variables.

\section{The Measurement Model}

The measurement model indicated a good fit, $\chi^{2}(193, \mathrm{~N}=325)=295.75, \mathrm{p}<.001, \mathrm{CFI}=.96, \mathrm{NNFI}=.95$, RMSEA $=.04$. Table 1 provides composite reliability $(\mathrm{CR})$, average variance extracted (AVE), and Joreskog' $\rho$ for all constructs of the sample. Hair et al. (1998) recommend a CR above the 0.70 threshold and an AVE above the 0.50 threshold. Given that the values respected the recommended cut-off, one can conclude that the measurement model provides evidence of the reliability, convergent validity and discriminant validity of the measures. 
Table 1. Measurement model $(\mathrm{N}=327)$

\begin{tabular}{|c|c|c|c|c|}
\hline Items & Loadings & C.R. & Jöreskog $\rho$ & AVE \\
\hline Helping & & .85 & .92 & .70 \\
\hline I give of my time to help other agents who have work-related problems & .861 & & & \\
\hline $\begin{array}{l}\text { I am willing to take time off from my own busy schedule to help recruit } \\
\text { new employees }\end{array}$ & .902 & & & \\
\hline I take steps to try to prevent problems with other agents in company & .700 & & & \\
\hline $\begin{array}{l}\text { I act as a " peacemaker» when others in the company have } \\
\text { disagreements }\end{array}$ & .858 & & & \\
\hline I am a stabilizing influence in the company when dissention occurs & .862 & & & \\
\hline $\begin{array}{l}\text { I « touch base » with others before initiating action that might affect } \\
\text { them (removed) }\end{array}$ & .452 & & & \\
\hline Civic virtue & & .70 & .94 & .86 \\
\hline I attend functions that are not required but help the company image & .716 & & & \\
\hline $\begin{array}{l}\text { I attend information sessions that agents are encouraged but not required } \\
\text { to attend }\end{array}$ & .719 & & & \\
\hline I attend and actively participate in company meetings & .521 & & & \\
\hline Sportsmanship (all scores reversed) & & .72 & .89 & .90 \\
\hline I always find fault with what the company is doing & .691 & & & \\
\hline I tend to make problems bigger than they are & .515 & & & \\
\hline $\begin{array}{l}\text { I always focus on what is wrong with a situation rather than the positive } \\
\text { side of it }\end{array}$ & .592 & & & \\
\hline I spend a lot of time complaining about trivial matters (removed) & .339 & & & \\
\hline Job search & & .88 & .95 & .88 \\
\hline I often seek information about other job possibilities & .780 & & & \\
\hline I often look at newspaper ads for new jobs & .921 & & & \\
\hline I sometimes follow up on job leads I've heard about & .928 & & & \\
\hline Intention to leave the employer & & .92 & .97 & .93 \\
\hline There is a good chance that I will leave this organization in the next year & .921 & & & \\
\hline I will probably look for a new organization in the next year & .965 & & & \\
\hline I frequently think of leaving this organization & .852 & & & \\
\hline Intention to leave the profession & & .92 & .97 & .93 \\
\hline There is a good chance that I will leave my profession in the next year & .921 & & & \\
\hline I frequently think of quitting my profession & .852 & & & \\
\hline I will probably look for a new profession in the next year & .965 & & & \\
\hline
\end{tabular}

Table 2 presents the descriptive statistics and correlations. As shown by the results, discriminant validity is demonstrated, since all AVE values are higher than the squared correlations between the constructs (Fornell and Larker, 1981). Thus, the results displayed in Tables 1 and 2 indicate that the measurement model is appropriate.

\section{Structural Equation Modeling}

The Research model examined forms of OCB as input to withdrawal cognitions. Therefore, our intention suggested a direction of causation. Because the design of the present study was cross-sectional, it was important to provide findings indicating that OCB predicts employee retention rather than findings showing correlations. Coyne and Ong (2007, p. 1094) suggest that "future research would need to employ more longitudinal designs to examine in more detail whether OCB does predict turnover intention or whether turnover intention actually predicts OCB behaviour." Consistent with Coyne and Ong, the research model was compared to two alternative models. Model 1 (first alternative model) considered the indirect relationship between job search and withdrawal intentions via forms of OCB and examined (1) paths linking intentions to search and forms of OCB; (2) paths linking forms of OCB and intention to withdrawal. Model 2 (second alternative model) considered forms of OCB as output to withdrawal cognitions. Model 2 examined (1) paths linking intention to search and intention to withdrawal; and (2) paths linking intention to withdrawal and forms of OCB. The chi-square difference test (Bentler and Bonnett, 1980) suggested that the Research model improved the fit compared to Model 1, $\chi^{2}$ diff $(2)=13,9, p<.001$, and to Model $2, \chi^{2}$ diff $(4)=$ $23,3, \mathrm{p}<.001$. 
Table 2. Average, standard deviation and correlations $(\mathrm{N}=325)$

\begin{tabular}{|c|c|c|c|c|c|c|}
\hline & 1. & 2. & 3. & 4. & 5. & 6. \\
\hline \multicolumn{7}{|l|}{ 1. Helping } \\
\hline 2. Civic virtue & $.42 * *$ & & & & & \\
\hline 3. Sportsmanship & $.14 *$ & $.23 * *$ & & & & \\
\hline 4. Job search & -.04 & -.03 & $-.39 * *$ & & & \\
\hline 5. Intent to leave employer & -.11 & $-.13 *$ & $-.46 * *$ & $.57 * *$ & & \\
\hline 6. Intent to leave profession & -.10 & $-.18 * *$ & $-.40 * *$ & $.44^{* *}$ & $.49 * *$ & - \\
\hline Mean & 27.75 & 14.90 & 15.26 & 11.76 & 7.08 & 6.65 \\
\hline Standard Deviation & 4.31 & 3.42 & 3.21 & 5.64 & 4.68 & 4.24 \\
\hline Maximum & 35 & 21 & 21 & 21 & 21 & 21 \\
\hline Minimum & 5 & 3 & 3 & 3 & 3 & 3 \\
\hline
\end{tabular}

Table 3 shows the standardized estimates of the causal links and the values of Student's t-test for all of the relations examined in the study. The research model indicated that OCB is linked to intention to leave the employer and intention to leave the profession through intention to job search. The fit of the research model to the data was good, $\chi^{2}(164, \mathrm{~N}=325)=411.48, \mathrm{p}<.001, \mathrm{CFI}=.91, \mathrm{NNFI}=.89$, RMSEA $=.07$. As shown by the results of the Chi-square difference test (Bentler and Bonnett, 1980), the addition of direct causal links between types of organizational citizenship and intention to leave the organization and intention to leave the profession improved Model 2, $\chi^{2}(156, \mathrm{~N}=325)=346.6, \mathrm{p}<.001, \mathrm{CFI}=.93, \mathrm{NNFI}=.91, \mathrm{RMSEA}=.06$.

Hypothesis 1 predicted a negative relationship between OCB toward individuals and intention to leave the employer. Consistent with previous findings (Paillé, 2009), two sub-dimensions emerged for describing OCB toward individuals. These sub-dimensions were labelled altruism and helping. While altruism was negatively related to intention to leave the employer ( $\beta=-.140, \mathrm{p}<.05)$, helping was not $(\beta=-.058, \mathrm{~ns})$. Although only altruism was linked, we consider that the data supported Hypothesis 1.

Hypothesis 2 predicted a negative relationship between civic virtue and intention to leave the employer. Consistent with the prediction, civic virtue was negatively related to intention to leave the organization $(\beta=-.124, p$ $<.05)$. Data supported Hypothesis 2.

Hypothesis 3 predicted a negative relationship between sportsmanship and intention to leave the employer. A significant relation was found. However, while a negative relationship was expected, data reported a positive relation $(\beta=.309, \mathrm{p}<.001)$. Thus, data partially supported Hypothesis 3 .

Hypothesis 4 predicted a negative relationship between OCB toward the individuals and intention to leave the profession. Contrary to the prediction, both altruism $(\beta=-.105, \mathrm{~ns})$ and helping $(\beta=.052$, ns) were not related to intention to leave the profession. Therefore, Hypothesis 4 was not supported.

Hypothesis 5 predicted a negative relationship between civic virtue and intention to leave the profession. Consistent with the prediction, civic virtue was negatively related to intention to leave the profession $(\beta=-.284, \mathrm{p}<$ .001). Thus, Hypothesis 5 was supported.

Hypothesis 6 predicted a positive relationship between sportsmanship and intention to leave the profession. Consistent with the prediction, sportsmanship and intention to leave the profession were positively related ( $\beta=.317$, $\mathrm{p}<.001)$. Therefore, Hypothesis 6 was supported. 
Table 3. Paths analyses results

\begin{tabular}{|c|c|c|c|c|c|c|}
\hline & & & \multicolumn{2}{|c|}{ Model 1} & \multicolumn{2}{|c|}{ Model 2} \\
\hline \multicolumn{3}{|c|}{ Relationship } & $\beta$ standardised & t value & $\beta$ standardised & t value \\
\hline Helping & $\rightarrow$ & Search a job & .053 & .889 & .053 & .876 \\
\hline Altruism & $\rightarrow$ & Search a job & .060 & 1.729 & .093 & 1.268 \\
\hline Civic virtue & $\rightarrow$ & Search a job & $-.141^{*}$ & -2.158 & -.119 & -1.833 \\
\hline Sportsmanship & $\rightarrow$ & Search a job & $.467 * * *$ & 4.851 & $.447 * * *$ & 4.748 \\
\hline Search a job & $\rightarrow$ & QProfession & $.468 * * *$ & 7.502 & $.272 * * *$ & 3.915 \\
\hline Search a job & $\rightarrow$ & QEmployer & $.604 * * *$ & 10.545 & $.446^{* * *}$ & 6.701 \\
\hline Helping & & QProfession & & & .052 & .937 \\
\hline Altruism & & Qprofession & & & -.105 & -1.522 \\
\hline Civic virtue & & QProfession & & & $-.284 * * *$ & -4.268 \\
\hline Sportsmanship & & QProfession & & & $.317 * * *$ & 3.536 \\
\hline Helping & & QEmployer & & & -.058 & -1.098 \\
\hline Altruism & & QEmployer & & & $-.140 *$ & -1.999 \\
\hline Civic virtue & & QEmployer & & & $-.124 *$ & -2.164 \\
\hline Sportsmanship & $\rightarrow$ & QEmployer & & & $.309 * * *$ & 3.646 \\
\hline \multicolumn{3}{|c|}{ Chi-square } & \multicolumn{2}{|c|}{411.48} & \multicolumn{2}{|c|}{346.6} \\
\hline \multicolumn{3}{|c|}{ Degree of freedom } & \multicolumn{2}{|c|}{164} & \multicolumn{2}{|c|}{156} \\
\hline \multicolumn{3}{|c|}{ NNFI } & \multicolumn{2}{|c|}{.89} & \multicolumn{2}{|c|}{.91} \\
\hline \multicolumn{3}{|l|}{ CFI } & \multicolumn{2}{|c|}{.91} & \multicolumn{2}{|c|}{.93} \\
\hline \multicolumn{3}{|l|}{ RMSEA } & \multicolumn{2}{|c|}{.07} & \multicolumn{2}{|c|}{.06} \\
\hline
\end{tabular}

$\Delta \chi 2(12)=64.88, \mathrm{p}<.001$

Notes: $* * * \mathrm{p}=.000 * \mathrm{p}=.05$; ILEmployer : intent to leave the employer; ILProfession : intent to leave profession

Hypothesis 7 predicted that OCBs affect intention to leave the employer, and intention to leave the profession through job search, respectively. Sportsmanship was related to intention to job search $(\beta=.447, \mathrm{p}<$ .001 ), unlike civic virtue, altruism and helping, which were not. In line with the literature on the cognitive process of withdrawal, the results also indicated that intention to job search was positively related to intention to leave the employer $(\beta=.446, \mathrm{p}<.001)$ and intention to leave the profession $(\beta=.272, \mathrm{p}<.001)$. These results suggest that job search plays a partial mediating role between sportsmanship and intention to leave the organization, and intention to leave the profession. The Sobel test (Sobel, 1982) was performed to assess the significance of the partial mediation. Results revealed that paths linking sportsmanship and intention to leave the profession $(\mathrm{z}=2.036, \mathrm{p}=$ $0.04)$, and intention to leave the organization $(\mathrm{z}=1.986, \mathrm{p}=0.04)$ through search a job were significant. Thus, this means that hypothesis 7 , and 8 were supported.

\section{DISCUSSION}

\section{Contributions of This Research}

This paper reports findings showing how OCB are related to job search and intention to leave the employer and intention to leave the profession. The results of this research also improve our understanding of the correlation between OCB and employee retention. Several recent studies have shown that empirical research seldom makes a distinction between retention and turnover (Wermeling, 2009) or makes it difficult to determine whether employees leave their employer or their profession (Parry, 2008). This research shows that a more detailed analysis of employee retention requires data indicating as precisely as possible whether employees intend to leave their employer or their profession. The improved understanding of these correlations is based on several key research decisions. First, the decision to use different dimensions of OCB rather than a global measure was useful to determine the specific dimensions of OCB involved in employee retention. The majority of previous field studies (Chen, 2005; Chen et al., 1998; Koys, 2001; Mossholder, Setton and Henagan, 2005; Thau et al., 2004) focused on a global measure of organizational citizenship. As such, the results of previous studies only provide a partial understanding of the relationship between OCB and employee retention (e.g., Coyne and Ong, 2007). There are few empirical studies that examine the different dimensions of citizenship to determine the dimensions of citizenship that best explain the desire of an employee to terminate employment. By focusing on dimensions of OCB, this research shows that intention to leave the employer is explained by helping, civic virtue and sportsmanship and that intention to leave the profession is explained only by civic virtue and sportsmanship. More specifically, the data indicate that 
while certain dimensions of OCB promote employee retention (altruism and civic virtue), other dimensions of OCB (sportsmanship) tend to increase the risk of employees leaving their employer or changing professions. The following sections discuss the contributions of the paper.

First, the study highlights the empirical links between OCB and intention to leave the profession. Because little work has been done on this topic, the present study makes interesting contributions. Our data was useful in determining the impact of OCB on the decision to change professions. More precisely, while OCB directed towards the organization (civic virtue and sportsmanship) is related to intention to leave the profession, OCB directed towards individuals (altruism and helping) is not related to intention to leave the profession. We initially found that sportsmanship (ability to tolerate excessive demands) was the better predictor of intention to leave the profession. Secondly, while sportsmanship was positively related (suggesting that the more an employee demonstrates good sportsmanship the more the employee wants to leave the current profession to join another profession), civic virtue (individual contribution to the defence of the interests of the organization) was negatively related, indicating that personal interest in governance issues was not compatible with the desire to leave the profession. In earlier studies, these relations had been explained only theoretically by Lavelle (2010), or examined indirectly via cognate concepts such as career plateau (Chay, et al., 1995) or internal career path (Chompookum and Derr, 2004). The results of this research improve our understanding of the links between OCB and profession. Finally, no relationship was found between OCB directed towards the individual, such as altruism and helping. In addition, our study suggests that people do not associate OCB directed towards individuals with profession. Thus, when an employee experiences limited helping, our findings suggest that the employee seems to relate bad experiences to the working context rather than to the characteristics of the profession. In sum, we found that only OCB directed towards the organization was related to intention to leave the profession and, secondly, that sportsmanship was positively related and that civic virtue was negatively related.

Part of the data generated by this study confirms the findings outlined in previous studies on the relationship between OCB and intention to leave the organization. Overall, and consistent with the meta-analysis of Podsakoff et al. (2009), our findings indicate that OCB towards the organization better explains turnover intentions than OCB towards individuals. Moreover, in line with previous theoretical interpretations (Organ et al., 2006), and empirical data provided by field studies (e.g., Paré and Tremblay, 2007), our findings indicate that altruism or helping in the workplace contributes to fostering employee retention. Additional findings were provided by the decomposition of OCB towards the organization into two facets reflecting sportsmanship and civic virtue. Consistent with Coyne and Ong (2007), and Paillé (2013) our research reports that, among the facets of OCB (altruism, helping, civic virtue, and sportsmanship used in this study, sportsmanship is the better predictor of intention to leave the employer. However, while Coyne and Ong (2007) reported negative relationship suggesting the more an employee displays good sportsmanship, the less the employee wants to leave the employer, our data reports a positive relationship indicating that good sportsmanship enhances the probability that an employee will leave an employer. Whereas a significant relationship was expected, the direction of the relationship was not. Somewhat surprisingly, this finding is consistent with the opinion of Organ and Ryan (1995) and the data obtained by Bolino and Turnley (2005), who reported data indicating that high levels of OCB increase stress. However, Bolino and Turnley (2005) used a measure of individual initiative to operationalize OCB. As defined by Podsakoff et al. (2000), individual initiative reflects a form of OCB by which an employee "engages in task-related behaviours at a level that is so far beyond minimally required or generally expected levels that it takes on a voluntary flavour." Although the present study did not explore the relationship between OCB and a stressful job-related variable, our findings are consistent with these previous data. The fact that the participants (social workers) used for the study are acknowledged as having a stressful occupation (Wermeling, 2009) contributes to explaining the positive relationship between sportsmanship and intention to leave the employer. Our data suggest that an excessive level of sportsmanship increases the probability of an exit from a stressful work environment by changing employers. In addition, contrary to Coyne and Ong (2007), who reported no significant correlation between civic virtue and intention to leave the employer, our research reports a negative relationship, suggesting that the more an employee demonstrates a willingness to protect an employer, the more the employee desires to leave the employer. In sum, we found that sportsmanship, civic virtue and altruism predict an intention to leave the employer and, secondly, that sportsmanship is the best predictor. Thirdly, while altruism and civic virtue are negatively related, sportsmanship is positively related. 
The focus on job-search behaviour generated original data. This study improves our understanding of the role of the cognitive variables involved in the relationship between OCB and withdrawal cognitions. Our findings indicate that job search merely mediates the relationship between sportsmanship and intention to leave the profession, and intention to leave the employer. Although we recognize that the Sobel tests are significant but near the standard cut-off of $p=.05$, these results are particularly instructive. From the perspective of improving our understanding of the impact of OCB on employee retention, the focus on job-search behaviour shows that in a job context perceived as making excessive demands (sportsmanship), employees tend to seek a job in another organization and remain in the same profession prior to looking for a job in another profession. This previous comment is consistent with what Dalton and Todor (1993) refer to as 'transfer'. Transfer mechanisms imply that the employee prefers to search for a job in the same organization in order to retain cumulative fringe benefits rather than search for a job in another organization. By applying the transfer mechanism to the profession, our findings suggest that an employee prefers to transfer within the profession before planning to search for a job in another profession. In addition, it was found that job-search behaviour does not play a mediating role between altruism and civic virtue, intention to leave the employer and intention to leave the profession. The observation that altruism is negatively related to intention to leave the employer and not related to job search is consistent with Mossholder et al. (2005), who argue that "individuals view their interpersonal citizenship behaviour as an investment that increases their value to an organization and profession." OCB directed towards individuals encourages the sharing of knowledge and tricks of the trade between employees and the improvement of technical skills (Organ et al. 2006) and, as such, contributes to retaining employees. Finally, the findings suggest that civic virtue creates a sense of responsibility towards the organization that appears to be incompatible with the desire to leave the employer and the profession in the near future. The sense of responsibility may explain why job search does not play a mediating role between civic virtue and the intention to leave both the employer and the profession.

\section{Practical Implications}

From the standpoint of factors that improve our understanding of the management of employee retention, the results of this research suggest that job-search behaviour may be a useful indicator for understanding employee intentions. Job-search behaviour represents a significant addition to the range of OCB. According to Chen (2005), when an employee engages more sparingly in OCB, this is highly indicative of the likelihood of intention to leave the employer. With job-search behaviour, the probability of changing the employer increases significantly if the search for a new job is fruitful and results in a job offer.

Sportsmanship refers to the willingness of an employee to tolerate a heavy workload. The fact that sportsmanship plays a major role is congruent with previous research (Bakker and Demerouti, 2007) on the perceived demands of a job. Based on the results of their literature review, Bakker and Demerouti inferred, for instance, that employees are willing to work under pressure if they feel supported in their work environment. The results of the present study suggest that sportsmanship can be used as an indicator of the level of pressure experienced by an employee and of his intention to leave (or remain in) a work environment perceived as demanding in terms of time, pressure and workload. While sportsmanship indicates the extent to which an employee is committed to an organization, it is indicative primarily of the intention to leave (or remain in) the organization and the willingness of an employee to redirect his career by changing profession. Given the high costs associated with employee resignation and change of profession, managers need to be aware of the deleterious psychological, organizational and social effects of work overload.

\section{Limitations of the Study and Future Research}

Despite its contributions to the OCB literature, this study has several limitations. First, an important limitation is the use of self-reporting measures of OCB. However, we observed that researchers differ in their perception of the difficulties associated with various data acquisition techniques. Some researchers (e.g., Organ and Ryan, 1995) feel that this choice produces somewhat biased results and encourages the use of responses reported by a third party to avoid interference from respondents' subjective views. Others (e.g., Conway and Lance, 2010; Turnipseed, 2002) see the use of methods based on self-reporting as justifiable when the investigation is focused on an examination of links between psychological variables. Indeed, as Meierhans, Reitmann and Jonas (2008, p. 139) argue, "the assumption underlying the use of self-reports is that OCB is generally not carried out in front of the 
supervisor and is therefore better known to the actor himself." Clearly, the choice of collecting data with selfreported measures may, nonetheless, lead to a bias in common variance liable to overestimate research results, due more particularly to the phenomenon of social desirability (Spector, 1987). But as indicated by Schnake (1991, p. 741) "supervisor ratings may be biased as a result of halo, or deficient because citizenship is so difficult to observe." Lastly, Van Dyne and Cummings (1990) point out that both self-report and supervisor ratings of OCB have serious weaknesses (cited by Schnake, 1991). Finally, the measurement of OCB (self-reports vs. supervisor or co-worker ratings) creates unresolved issues. Future research could add more sources (self-rating, supervisor-rating and coworker-rating) in order to neutralize the threat of common variance. In addition, further research might benefit from using a longitudinal design to control the stability of the different relations between the variables.

Secondly, this research focused primarily on the links between OCB and employee retention. Although the present research did not examine the possible influence of stressful variables linked to profession, or job on OCBs, our results are compatible with the conclusions of the meta-analysis conducted by Mor Barak, Nissly and Levin (2001) indicating that perceived stress among social workers is the variable that best explains intention to change employers. As highlighted above, job-related negative experiences (e.g., job stress, exhaustion, work overload, etc.) affect OCB. Previous findings in the field of social work reported a negative relationship between job-related negative experiences and the decision to leave (Kim and Stoner, 2008). Therefore, our data suggest that future research might explore OCB as a variable on the effect of job-related negative experiences on intention to leave the employer and intention to leave the profession. In addition, career plateau is probably a common determinant of both $\mathrm{OCB}$ and intention to leave the profession and the organization. As a plausible hypothesis, future research might examine the effect of perception of career plateau on both OCB and the decision to leave.

Thirdly, the Research model examined forms of OCB as input to withdrawal cognitions. As such, a direction of causation was proposed between OCB and withdrawal cognitions. However, we are aware that in the design chosen for this study, a limitation does exist in relation to the difficulty of inferring causality (Bobko and Stone-Roméro, 1988). Therefore results cannot be used to determine if withdrawal cognitions have an impact on OCBs, or if OCBs have an impact on withdrawal cognitions. A duplication of this study using a longitudinal design would mitigate this limitation.

\section{CONCLUSION}

The results of this research improve our understanding of the nature of the relationship between OCB and employee retention. One significant result relates to the role of sportsmanship in employee retention, indicating that employee retention in relation to the employer and to the profession depends largely on the level of individual tolerance of excessive work demands. Though interesting and compatible with the current trend towards work intensification, further studies are needed to improve our understanding of the relations between OCB and employee retention.

\section{AUTHOR INFORMATION}

Pascal Paillé is full professor at Laval University, where he is the Director of the $\mathrm{PhD}$ and Master Research Program of Faculty of Business Administration. His research focuses on employee retention, green human resource management, and pro-environmental behaviors at job. His research has been published in the Journal of Business Ethics, International Journal of Human Resource Management, Journal of Environmental Psychology, Business, Strategy and the Environment, Journal of Applied Business Research, among others. E-mail: Pascal.Paille@fsa.ulaval.ca

Nicolas Raineri is currently postdoctoral fellow at the Universite Catholique de Louvain-la-Neuve, Belgium. He earned his Ph.D. at the Laval Univertity. His research focuses on human resource in sustainability context. His research has been published in the Journal of Business Ethics, Journal of Organizational Ethnography, and Critical Perspectives on Accounting.

Patrick Valeau is associate professor at University of La Réunion, where he is the Director of Research in Management. His current research focuses on human resource management in the context of nonprofit 
organizations. His research has been published in the International Journal of Voluntary \& Nonprofit Organizations and Canadian Journal of Behavioral Science, among others.

\section{REFERENCES}

Anderson, J.C., and Gerbing, D.W. (1988). Structural Equation Modeling in Practice: A Review and Recommended Two-Step Approach. Psychological Bulletin, 103, 411-423.

Arbuckle, K. (2009). Amos 5.0. Update to the Amos. User's Guide. Chicago. IL, SmallWaters Corporation.

Armony, V. (2002). Des Latins du Nord? L'identité culturelle québécoise dans le contexte panaméricain. Recherches sociographiques, 43, 1, 19-48.

Bakker, A., and Demerouti, E. (2007). The Job Demands-Resources model: state of the art. Journal of Managerial Psychology, 22, 3, 309-328

Bentler, P.M., and Bonnett, D.C. (1980). Significance tests and goodness of fit in the analysis of covariance structures. Psychological Bulletin, 80, 588-506.

Blau, G. (2009). Can a four-dimensional model of occupational commitment help to explain intent to leave one's occupation? Career Development International, 14(2), 116 - 132.

Blau, G. and Lunz, M. (1998). Testing the Incremental Effect of Professional Commitment on Intent to Leave One's Profession beyond the Effects of External, Personal, and Work-Related Variables. Journal of Vocational Behavior, 52, 260-69.

Bobko, P, and Stone-Romero, E.F. 1998. Meta-analysis may be another useful research tool, but it is not a panacea. In Ferris G.R. (ed.) Research in Personnel and Human Resources Management, (pp. 359-397), Stamford, CT., JAI Press.

Bolino, M.C., \& Turnley, W.H. (2005). The Personal Costs of Citizenship Behavior: The Relationship between Individual Initiative and Role overload, Job Stress, and Work-Family Conflict. Journal of Applied Psychology, 90, 740-748.

Boswell, W. R., and Olson-Buchanan, J. B. (2004). Experiencing Mistreatment at Work: The Role of Grievance Filing, Nature of Mistreatment, and Employee Withdrawal. The Academy of Management Journal, 47, 1, 129-139.

Browne, R., and Cudeck, M. W. (1992). Constructing a covariance matrix that yields a specified minimizer and a specified minimum discrepancy function value. Psychometrika, 57, 3, 357-369

Chay, Y. W., Aryee, S. and Chew, I. (1995). Career plateauing: reactions and moderators among managerial and professional employees. The International Journal of Human Resource Management, 6, 1, 61-78.

Chen, X.-P., Hui, C., and Sego, D.J. (1998). The Role of Organizational Citizenship Behavior in Turnover: Conceptualization and Preliminary Tests of Key Hypotheses. Journal of Applied Psychology, 83, 6, 922931.

Chen, X.-P (2005). Organizational Citizenship Behavior: A Predictor of Employee Voluntary Turnover. In Turnipseed, D.L. Handbook of Organizational Citizenship Behavior: A Review of 'Good Solder' Activity in Organizations (pp. 435-454), New-York, N-Y, Novasciences Publisher.

Chu, C.-I. Lee, M.L. and Hsu, H.M. (2006). The Impact of Social Support and Job Stress on Public Health Nurses' Organizational Citizenship Behaviors in Rural Taiwan. Public Health Nursing 23, 6, 496-505.

Chompookum, D. and Derr, C. B. (2004). The effects of internal career orientations on organizational citizenship behavior in Thailand. Career Development International, 9, 4, 406-423.

Conwey, J.M., and Lance, C.E. (2010). What Reviewers Should Expect from Authors Regarding Common Method Bias in Organizational Research. Journal of Business and Psychology, 25, 325-334.

Coyne, I. and Ong, T., (2007). Organizational citizenship behaviour and turnover intention: a cross-cultural study. The International Journal of Human Resource Management, 18, 6, 1085-1097.

Dalton, D., and Todor, W. (1993). Turnover, Transfer, Absenteeism: An Interdependent Perspective. Journal of Management, 19, 2, 193-219.

Dozier, J.B., and Miceli, M.P. (1985). Potential Predictors of Whistle-Blowing: A Prosocial Behavior Perspective. The Academy of Management Review, 10(4), 823-836.

Eastman, K. and Pawar, B.S. (2005). An integrative View of and a Common Conceptual Space for Employee ExtraRole Behaviors. In Turnipseed, D.L. Handbook of Organizational Citizenship Behavior: A Review of 'Good Solder' Activity in Organizations (pp. 25-46), New-York, N-Y, Novasciences Publisher.

Farh, J. L., Early, P. C., and Lin, S. C. (1997). Impetus for action: A cultural analysis of justice and organizational 
citizenship behavior in Chinese society. Administrative Science Quarterly, 42, 421-444.

Flinkman M., Laine M., Leino-Kilpi H., Hasselhorn H.-M. and Salanterä S. (2008) Explaining young registered Finnish nurses' intention to leave the profession: a questionnaire survey. International Journal of Nursing Studies, 45, 727-739.

Fornell, C., and Larker, D.F. (1981). Evaluating structural equations models with unobservable variables and measurement error. Journal of Marketing Research, 18, 39-50.

Foster, B.P., Shastri, T., and Witane, S. (2004). The Impact of Mentoring On Career Plateau And Turnover Intentions Of Management Accountants. Journal of Applied Business Research, 20, 4, 33-43.

Griffeth, R., Hom, P., and Gaertner, S. (2000). A Meta-Analysis of Antecedents and Correlates of Employee Turnover: Update, Moderator Tests, and Research Implications for the Next Millennium. Journal of Management, 26, 3, 463-488.

Gupta, N. et Jenkins, G. D. (1983). Tardiness as a manifestation of employee withdrawal. Journal of Business Research, 2, 61-75.

Hanisch, K. A., and Hulin, C. L. (1990). Job attitudes and organizational withdrawal: An examination of retirement and other voluntary withdrawal behaviors. Journal of Vocational Behavior, 37, 60-78.

Harrison, D.A., Newman, D.A., and Roth, P.L. (2006). How Important are Job Attitudes? Meta-analytic Comparisons of Integrative Behavioral Outcomes and Time Sequences. Academy of Management Journal, 49, 2, 305-325.

Holtom, B. C., Mitchell, T. R., Lee, T. W., and Inderrieden, E. J. (2005). Shocks as Causes of Turnover: What they are and how Organizations Can Manage Them. Human Resource Management, 44, 3, 337-352.

Hom, P. and Griffeth, R., (1995). Employee turnover. Cincinnati, HO, South-Western.

Kanfer, R., Wanberg, C.R. and Kantrowitz T.M. (2001). Job Search and Employment: A Personality-Motivational Analysis and Meta-Analytic Review. Journal of Applied Psychology, 86(5), 837-855.

Kim, H. and Stoner, M. (2008). Burnout and Turnover Intention Among Social Workers: Effects of Role Stress, Job Autonomy and Social Support. Administration in Social Work, 32, 5- 25.

Koys, D. (2001). The effects of employee satisfaction, Organizational Citizenship Behavior, and turnover on organizational effectiveness: A unit-level, longitudinal study. Personnel Psychology, 54, 101-114.

Krausz, M., Koslowsky M., Shalom, N., and Elyakim, N. (1995). Predictors of intentions to leave the ward, the hospital, and nursing profession: Longitudinal study. Journal of Organizational Behavior, 16, 277-288.

Lavelle, J. J. (2010). What motivates OCB? Insights from the volunteerism literature. Journal of Organizational Behavior, 31, 918-923.

Lemire, L., Saba, T. and Gagnon, Y.-C. (1999). Managing Career Plateauing in the Quebec Public Sector. Public Personnel Management, 28, 375-391.

LePine, J., Erez, A., and Johnson, D. (2002). The nature and dimensionality of organizational citizenship behavior: A critical review and meta-analysis. Journal of Applied Psychology, 87, 1, 52-65.

Lichtenstein, R., Alexander, J.A., McCarthy, J.F., and Wells, R. (2004). Status Differences in Cross-Functional Teams: Effects on Individual Member Participation, Job Satisfaction, and Intent to Quit. Journal of Health and Social Behavior, 3, 322-335.

Lu, K.Y., Lin, P.L., Wu, C.M., Hsieh, Y.L. and Chang, Y.Y. (2002). The Relationships Among Turnover Intentions, Professional Commitment, and Job Satisfaction of Hospital Nurses. Journal of Professional Nursing, 18, (4), pp 214-219

MacKenzie, S., Podsakoff, P., and Ahearne, M. (1998). Some Possible Antecedents and Consequences of In- Role and Extra-Role Salesperson Performance. Journal of Marketing, 62, 87-98.

Meierhans, D., Rietmann, B., and Jonas, K. (2008). Influence of fair and supportive leadership behavior on commitment and organizational citizenship behaviour. Swiss Journal of Psychology, 3, 131-41.

Meyer, J.P., Allen, N.J. and Smith, C.A. (1993). Commitment to Organizations and Occupations: Extension and Test of a Three-Component Conceptualization. Journal of Applied Psychology, 78(4), 538-551.

Miles D, Borman, W., Spector, P.E., and Fox, S. (2002). Building an Integrative Model of Extra Role Work Behaviors: A Comparison of Counterproductive Work Behavior with Organizational Citizenship Behavior. International Journal of Selection and Assessment, 10 (1/2), 51-57.

Moon, H. Van Dyne, L. and Wrobel, K. (2005). The circumplex model and the future of organizational citizenship behavior research. In Turnipseed, D.L. Handbook of Organizational Citizenship Behavior: A Review of 'Good Solder' Activity in Organizations (pp. 3-23), New-York, N-Y, Novasciences Publisher.

Mor Barak, M.E., Nissly, J.A., and Levin, A. (2001). Antecedents to Retention and Turnover among Child Welfare, 
Social Work, and Other Human Service Employees: What Can We Learn from Past Research? A Review and Metanalysis. The Social Service Review, 75 (4), 625-661.

Mossholder, K.W., Settoon, R.P., and Hanagan, S.C. (2005). A relational perspective on turnover: Examining structural, attitudinal, and behavioural predictors. Academy of Management Journal, 48, 4, 607-618.

Mowday, R.T., Koberg, C.S., and McArthur, A.W. (1984). The Psychology of the Withdrawal Process: A CrossValidational Test of Mobley's Intermediate Linkages Model of Turnover in Two Samples. The Academy of Management Journal, (27)1, 79-94.

Near, J. P. (1984). Reactions to the Career Plateau. Business Horizons, 75-70.

Netemeyer, R.G., Bearden, W.O., and Sharma, S. (2003) Scaling procedures: Issues and applications. Thousand Oaks: Sage Publications.

Nunnally, J. C., and Bernstein, I. (1994). Psychometric theory. McGraw-Hill, New York.

Organ, D. (1988) Organizational citizenship behavior: The good soldier syndrome. Lexington books: Lexington, MA.

Organ, D.W., Podsakoff, P.M., and Mackensie, S.B., (2006). Organizational Citizenship Behavior. Its Nature, Antecedents, and Consequences. Sage Publication, Thousands Oaks.

Organ, D., and Ryan, K. (1995). A Meta-analytic review of attitudinal and dispositional predictors of organizational citizenship behaviour. Personnel Psychology, 48, 775-802.

Parry J. (2008) Intention to leave the profession: antecedents and role in nurse turnover. Journal of Advanced Nursing, 64(1), 57-167.

Paine, J. B., and Organ, D. W. (2000). The cultural matrix of organizational Citizenship behavior: Some preliminary conceptual and Empirical observations. Human Resource Management Review, 10, 1, 45-59.

Paillé, P. (2009). Assessing Organizational Citizenship Behaviour in the French Context: Evidence for the Four

Dimensional Model. The Journal of Psychology, 143, 2, 133-146.

Peters, L., Jackofsky, E., and Salter, J. (1981). Predicting turnover: A comparison of part-time and full-time employees. Journal of Occupational Behavior, 2, 89-98.

Podsakoff, P. M., and MacKenzie, S. B. (1994). Organizational citizenship behaviors and sales unit effectiveness. Journal of Marketing Research, 3, 351-363.

Rhee, J., Park T., and Hwang, S.H. (2011). Non-regular professionals' dual commitment in South Korea: antecedents and consequences. The International Journal of Human Resource Management, 22, (3), 612-631.

Robinson, S. L., and Bennett, R. J. (1995). A Typology of Deviant Workplace Behaviors: A Multidimensional Scaling Study. Academy of Management Journal, 38(2), 555-572.

Rossé, J. (1988). Relations among Lateness, Absence, and Turnover: Is there a Progression of Withdrawal? Human Relations, 41, 7, 517-531.

Rosenholtz, S.J. (1989).Workplace Conditions That Affect Teacher Quality and Commitment: Implications for Teacher Induction Programs. The Elementary School Journal, 89 (4), 420-439.

Sager, J.K., Griffeth, R.W. \& Hom, P.W. (1998). A Comparison of Structural Models Representing Turnover Cognitions, Journal of Vocational Behavior, 53, 254-273.

Schaufeli, W.B. and Bakker, A.B. (2004). Job demands, job resources, and their relationship with burnout and engagement: a multi-sample study. Journal of Organizational Behavior, 25, 293-315.

Schnake, M. (1991). Organizational Citizenship: A Review, Proposed Model, and Research Agenda. Human Relations, 44 (7), 735-759.

Spector, P. E. (1987). Method variance as an artefact in self-reported affect and perceptions at work: Myth or significant problem? Journal of Applied Psychology, 86(1), 114-121.

Steel, R.P. (2004). Job markets and Turnover decisions. In R. Griffeth and P. Hom (Eds) Innovative Theory and Empirical Research on Employee Turnover (pp. 73-82). Information Age Publishing, Greenwich, Connecticut.

Tepper, B.J., Duffy, M.K., Hoobler, J., and Ensley, M.D., (2004). Moderators of the Relationships Between Coworkers' Organizational Citizenship Behavior and Follow Employees' Attitudes. Journal of Applied Psychology, 89, 3, 455-465.

Thau, S., Bennett, R.J., Stahlberg, D., and Werner, J.M. (2004). Why should I be generous when I have valued and accessible alternatives? Alternative exchange partners and OCB. Journal of Organizational Behavior, 25, 607-626.

Turnipsseed, D. (2002). Are good soldiers good? Exploring the link between organizational citizenship behavior and 
personal ethics. Journal of Business Research, 55, 1-15.

Van der Doef, M., and Maes, S. (1999). The Job Demand-Control (-Support) Model and psychological well-being: a review of 20 years of empirical research. Work and Stress, 13(2), 87-114

Van Dyne, L., and Cummings, L. (1990). Extra-role behaviors: The need for construct and definitional clarity. Paper presented at the Academy of Management Annual Meeting, San Franscisco, California.

Van Dyne L. and LePine J. A. (1998) Helping and Voice Extra-Role Behaviors: Evidence of Construct and Predictive Validity. The Academy of Management Journal, 41, 1, 108-119.

Wermeling, L. (2009). Social Work Retention Research: Three Major Concerns. Journal of Sociology, Social Work and Social Welfare, 3, 1, 1-7. 